\section{AFRICAN VEGETATION}

\section{MEETING AT YANGAMBI}

$\mathrm{T}$ HE study of natural vegetation, which has no regard for international boundaries, is of primary importance in the scientific development of Africa. It is therefore good to note that the Conseil Scientifique pour l'Afrique au Sud du Sahara, in conjunction with the Commission de Co-operation Technique en Afrique au Sud du Sahara, is now taking steps to promote international co-operation in this basic branch of science.

During July 29-August 8 this year a meeting of specialists in phytogeography was held in the Belgian Congo, under the presidency of Prof. J. Lebrun, secretary-general of the Institut National pour l'Etude Agronomique du Congo belge. 'The sessions were held at Yangambi, the African headquarters of the Institute, which is on the north bank of the Congo, about 90 kilometres downstream from Stanleyville, in dense evergreen rain forest. In 1885 , H. M. Stanley wrote, "Yangambi is beautifully situated on a level terrace. The summits of the ridge appear to offer a charming field for European agriculturists". 'To-day the Institute's impressive organization at Yangambi employs some two hundred Europeans.

The member-governments of the two sponsoring bodies were represented by Prof. J. Lebrun (Belgium), Prof. J. Trochain (France), Dr. R. A. Dyer (Union of South Africa), Prof. P. W. Richards (United Kingdom), Dr. F. A. Mendonça (Portugal) and Prof. A. S. Boughey (Federation of Rhodesia and Nyasaland). The other participants were Prof. .J. Millot, Prof. Th. Monod, A. Aubréville, Prof. Kr. Pichi-Sermolli, Dr. R. O. Whyte (Food and Agriculture Organization), R. W. T. Keay (sponsored by Unesco), and E. A. Bernard, Dr. R. Germain, E. Maudoux, R. Devred, L. Liben, C. Evrard and R. Gutzwiller, of the Institut National pour l'Étude Agronomique du Congo Belge.

In the field of plant taxonomy, international cooperation in Africa south of the Sahara is already well organized. The International Association of Plant Taxonomists and the Association pour l'Étude 'Taxonomique de la Flore d'Afrique Tropicale make important contributions towards this co-operation, the great national herbaria are in close contact with each other, and taxonomists-by and large---use much the same methods and concepts and accept comparable standards.

The position as regards plant ecology or phytogeography is, however, very different. There are, at the outset, considerable differences in the methods and concepts of the 'ecology' taught in British universities, largely influenced by Clements and Tansley, and the 'phytosociology' of the Braun-Blanquet school taught in most Firench and Belgian universities. The divergence has been aggravated by the fact that vegetation-mapping had been unfashionable in Britain during the past thirty years or so. Britishtrained botanists have, consequently, been going to Africa without much guidance on one of the first problems presented by African plant-life, so that ecological work has developed very individually in each territory. There is also a considerable difference, particularly outside the rain-forest regions, between the approach of the agriculturist who thinks of the vegetation as potential grassland, and that of the forester who thinks of the same vegetation as potential forest.
Much literature and many vegetation maps have been produced in recent years, but it is extremely difficult to correlate the work done by different authors, even in neighbouring African countries. The initiative taken by the Counseil Scientifique pour l'Afrique au Sud du Sahara in promoting international understanding in these matters is therefore most welcome.

The meeting at Yangambi was preceded by an interesting and well-organized excursion to the HautUele Province in the north-east Belgian Congo. After examining forests near Stanleyville, the party travelled by air $350 \mathrm{~km}$. north-east to Paulis. This important centre for Coffea robusta and cotton plantations lies in the rain-forest zone, and it was only after the party had travelled about $75 \mathrm{~km}$. toward Jungu that the first savannah vegetation was seen. All agreed that this vegetation and much of that seen on the journey $(210 \mathrm{~km}$.) next day to Aba had been derived from closed forest by man's farming and grassburning activities ; there was, however, a good deal of argument about the precise nature of the climax. Near Aba, the party saw a most interesting outlier of semi-evergreen rain-forest at Kurukwata, and later an example of the Isoborlizia doka woodlands, which are characteristic of a distinct belt stretching from French Guinea to Uganda and correspond to the wellknown 'myombo' woodlands of east, central and southern Africa.

This excursion, and two trips near Yangambi, provided a unique opportunity for some of Africa's leading ecologists to see together a good range of vegetation types and to discuss them in the field, while travelling, and at the end of each day. This field-work provided an excellent basis for the more formal meetings at Yangambi. There was a considerable measure of agreement concerning the recognition in the field of the plant communities and how they are influenced by biotic, edaphic and climatic factors. It was encouraging to find that on many points workers had independently come to similar conclusions. The greatest divergence of opinion was in matters concerning nomenclature and the concept of the climatic climax. The informal discussions about the latter more academic point were particularly lively and valuable.

Matters of nomenclature were dealt with in the formal sessions at Yangambi. MM. Aubréville, Trochain and Monod each presented classifications of the main types of tropical African vegetation. These and other participants worked hard during the meeting to produce a classification of physiognomic types with parallel names and diagnoses in French and English. This agreed synthesis is to form a basis for a synopsis of tropical African vegetation, illustrated by profile diagrams and photographs, which, it is hoped, M. Aubréville will shortly prepare for publication.

Prof. Monod presented a remarkable account, intended for publication, of the chorological divisions, that is, the broad patterns of distribution not only of the vegetation and plant species but also of the animals.

The meeting reviewed the present state of vegeta. tion-mapping in Africa south of the Sahara and proposed the creation of a permanent centre in Africa to which all new maps of interest to phy togeographers would be sent, and from which research workers conld borrow maps. It also considered proposals for the preparation of a botanical atlas of Africa, including vegetation maps on a scale of $1: 5,000,000$, as well as 
maps showing the distribution of economic species and other subjects.

The Conseil Scientifique pour l'Afrique au Sud du Sahara, and in particular Prof. Lebrun, are to be congratulated on organizing such a useful meoting, and it is to be hoped that means will be found to implement many of its recommendations.

R. W. J. KEAY

\section{NINTH INTERNATIONAL CONGRESS OF APPLIED MECHANICS}

$\mathrm{T}$

HE ninth International Congress of Applied

Mechanics was held at the Université Libre of Brussels during September 5-13. More than seven hundred members attended the Congress, and no less than five hundred communications were presented. The Congress was administered by the International Committee for Congresses of Mechanics, which is one of the organizations adhering to the International Union of Theoretical and Applied Mechanics. The president was Prof. F. van den Dungen and the secretary-general M. Jean Vandenkerckhove. A feature of the organization was the special provision which was made for young scientists, who were able to obtain cheap accommodation and meals in the Cité Universitaire, while a grant of 2,000 dollars was also available to help with their expenses of travelling to Brussels.

The main interest of the Congress naturally centred around the one-hour addresses. Mr. K. S. Davidson, of the Stevens Institute of Technology, Hoboken, N.J., gave a lecture on "Ships", in which hydrodynamics, boundary-layer theory and practical yachtsmanship were pleasantly combined. Much of the substance of this lecture is available in the Sir Geoffrey 'Taylor Memorial Volume entitled "Survoys in Mechanics" (Cambridge University Press, 1956).

Prof. R. Hill, of the University of Nottingham, gave a lecture on "New Horizons in the Mechanics of Solids". In this lecture he set up a theoretical framework sufficiently general to include problems of visco-elastic solids, including the theory of creep and work hardening.

Prof. P. Germain, of the University of Lille, lectured on "Some Recent Advances in Theoretical High Speed Aerodynamics". This was a general survey of problems of linearized supersonic theory treated by the method of the Laplace transform. Some extensions to second-order effects were also included in the lecture, which was remarkable for the speed with which it covered almost all recent developments in this subject.

Prof. H. Mettler, of the Technische Hochschule, Karlsruhe, spoke on "Forced Non-linear Vibrations of Elastic Bodies".

But perhaps the address which was most appreciated was that by Sir Geoffrey Taylor, which bore the title of "Steady Flow of Fluid entering a Region through Porous Boundaries", and which in fact dealt with the hydrodynamics of paper-making, and of painting with rollers and ordinary artists' brushes. In this extremely interesting address, Sir Geoffrey gave an account of the recent work which he has carried out to investigate the flow of the paper pulp over the rollers in paper-making machines. His investigations of roller painting and of brush painting consisted not only of simple theories embodying the main physical factors, but also of experiments which satisfactorily bore out the predictions of the theory and which were remarkable for the economy of material with which they were executed.

Apart from these general addresses, the work of the Congress was divided into two sections, the first dealing with fluid mechanies and containing some 258 papers, and the second with the mechanics of solids, containing 243 papers. In view of this great mass of material, it was necessary to limit the time available for the presentation of most papers to 15 minutes, although a certain number were givon 30 minutes. The papers were grouped in such a way that only two papers were ever being read at the same time, namely, a 30-minute paper in Section $\mathrm{I}$ and a 15-minute paper in Section II, or vice versa.

The section on fluid mechanics included papers on aerodynamics in subsonic, transonic, supersonic and hypersonic conditions, on atmospheric pollution, boundary-layer theory, hydrodynamics of waterentry problems and surface waves, lubrication, cavitation, and seepage problems in the Nile valley. A particularly interesting demonstration was given by Prof. M. Reiner, of the Israel Institute of Technology, of his centripetal pump. This machine consists of two parallel plates ground accurately flat, of which one forms the stator and the other the rotor. A pressure hole is located at the centre of the stator and the rotor is rotated at a few thousand revolutions per minute. Initially, the pressure at the centre of the stator is reduced; but as the distance between the plates is progressively reduced to a few thousandths of an inch, a pressure of several feet of water is built up.

The section on the mechanics of solids included some papers on classical problems of vibrations, on the elastic theory of plates and shells, on buckling and post-buckling problems, and on a yielding sub. soil ; but the emphasis seemed to be on plasticity, limit analysis, creep and visco-elasticity.

Mention must also be made of the social activities and of the financial support which the Congress received from Belgian banks and industries. Members of the Congress enjoyed the traditional Belgian hospitality at two receptions and a banquet. A reception was given at the University by the President, Vice-President and Rector of the Free University of Brussels and a reception at the Town Hall by M. L. Cooremans, mayor of Brussels. The banquet was held at the Hotel Metropole.

It is planned to hold the next International Congress of Applied Mechanics in 1960 in Italy.

\section{THE NUCLEI OF ATMOSPHERIC CONDENSATION}

A TMOSPHERIC aerosols cover a wide range of A particle-size from about $10^{-7} \mathrm{~cm}$. for the small ions to more than $10 \mu$ radius for the largest salt and dust particles, and a range of concentrations from less than $100 / \mathrm{cm}^{3}$ over the oceans and in the upper air to, perhaps, $10^{6} / \mathrm{cm}^{3}$ in the polluted air of large cities. Being the products of natural and man-mado combustion, of dust and spray raised from the Earth's surface, of chemical reactions taking place in the 